\title{
Radiomics imaging biomarkers from the perspective of tumor biology
}

Citation for published version (APA):

Sanduleanu, S. (2022). Radiomics imaging biomarkers from the perspective of tumor biology. [Doctoral Thesis, Maastricht University]. Maastricht University. https://doi.org/10.26481/dis.20220111ss

Document status and date:

Published: 01/01/2022

DOI:

10.26481/dis.20220111ss

Document Version:

Publisher's PDF, also known as Version of record

\section{Please check the document version of this publication:}

- A submitted manuscript is the version of the article upon submission and before peer-review. There can be important differences between the submitted version and the official published version of record.

People interested in the research are advised to contact the author for the final version of the publication, or visit the DOI to the publisher's website.

- The final author version and the galley proof are versions of the publication after peer review.

- The final published version features the final layout of the paper including the volume, issue and page numbers.

Link to publication

\footnotetext{
General rights rights.

- You may freely distribute the URL identifying the publication in the public portal. please follow below link for the End User Agreement:

www.umlib.nl/taverne-license

Take down policy

If you believe that this document breaches copyright please contact us at:

repository@maastrichtuniversity.nl

providing details and we will investigate your claim.
}

Copyright and moral rights for the publications made accessible in the public portal are retained by the authors and/or other copyright owners and it is a condition of accessing publications that users recognise and abide by the legal requirements associated with these

- Users may download and print one copy of any publication from the public portal for the purpose of private study or research.

- You may not further distribute the material or use it for any profit-making activity or commercial gain

If the publication is distributed under the terms of Article $25 \mathrm{fa}$ of the Dutch Copyright Act, indicated by the "Taverne" license above, 
PART I - PARADIGM SHIFT TOWARDS BIOLOGY-BASED ARTIFICIAL INTELLIGENCE-DERIVED IMAGING BIOMARKERS

In Chapter 2 we have performed a systematic literature search linking radiomics to tumor biology. All but two studies $(n=39$ ) revealed that radiomic features derived from ultrasound, CT, PET and/or MR are significantly associated with one or several specific tumor biologic substrates.

In Chapter $\mathbf{3}$ we have discussed several potentially interesting Al tools for clinical practice, such as automatic delineation in the context of volumetric treatment response evaluation (volumetric RECIST).

PART II - PARADIGM SHIFT TOWARDS USING IMAGING AND GENE EXPRESSION BIOMARKERS FOR TUMOR HYPOXIA DIAGNOSIS AND TREATMENT

In Chapter 4 we performed a literature review of characteristics of hypoxia PET tracers and in particular the tracer [18F]-HX4 and showed several benefits and limitations in comparison to the other PET tracers.

In Chapter 5/6 a radiomic lung, head and neck and agnostic signature on CT and FDG-PET was proposed in classifying tumors into hypoxic/ non-hypoxic classes based on different hypoxic fraction thresholds in external validation.

An agnostic CT model to classify hypoxia status (HF cutoff 20\%) reached AUC's of respectively $0.79 \pm 0.16,0.76 \pm 0.18$ and $0.72 \pm 0.14$ respectively in three external validation datasets by combining 5 CT-derived radiomic features. An agnostic FDG-PET model reached an AUC of $0.74 \pm 0.23$ in external validation by combining 10 features (HF cutoff 20\%). The lung-specific model reached an AUC of $0.80 \pm 0.15$ in external validation with $4 \mathrm{CT}$ features, while the H\&N-specific model reached an AUC of $0.86 \pm 0.20$ in external validation with 6 CT features.

Furthermore a significant survival split was found between CT-classified hypoxia strata was found as well as 117 significant yet low hypoxia response gene-CT signature feature associations.

In Chapter 7 we showed that in line with previous studies on [18F]-FMISO and [18F]-FAZA hypoxia PET tracers with our PET tracer [18F]-HX4 in two Dutch clinical trials and demonstrated that early hypoxia response to chemoradiation in $\mathrm{H} \& \mathrm{~N}$ cancer patients is of favorable prognostic value.

In Chapter 8 we have aimed to assess whether tumor markers that are related to hypoxia, proliferation, DNA damage repair and stem cell-ness, have a prognostic value in advanced stage HNSCC patients when assessed individually. Tumor acute and chronic hypoxia, stem cell-ness, and CD8+ T-cell parameters were all shown to be relevant and largely independent biological factors that together contribute to locoregional control.

\section{PART III - PARADIGM SHIFT TOWARDS BIOLOGY-DERIVED RADIOMICS AIDING IN LUNG AND HEAD AND NECK CANCER DIAGNOSIS AND TREATMENT}

In Chapter 9 we demonstrated that we can potentially enhance frozen section histology results by the addition of radiomics in solitary pulmonary nodules. This method may aid the surgeon in decision making about the most adequate type of surgery to remove a solitary nodule.

In Chapter $\mathbf{1 0}$ we aimed to identify peritumoral regions on CT in head and neck cancer patients and these regions may provide valuable information about (loco)regional and distant metastasis. In our experience, peritumoral regions did not seem to have predictive value for above mentioned outcomes. Several explanations may account for this: 1 ) The study endpoints are highly complex and prediction 
models have a hard time training generalizable models. 2) There were differences between the training and validation cohort related to the chemotherapy regimens used in the treatment of the patients.

In Chapter 11 we performed an in-depth analysis of CT scans obtained in daily clinical practice of LCNEC patients. The radiomics signature trained on scans of SCLC and NSCLC patients was able to identify SCLC and NSCLC in an external dataset. However, pSCLC-like and pNSCLC-like LCNEC could not be separated by this signature. The subclassification between molecular LCNEC subtypes could neither be made based on imaging interpretation or semantic features. In this study, experienced pulmonary oncologists and chest radiologists could fairly differentiate between SCLC and NSCLC based features provided by CT-scans. However, no difference between PSCLC-like and pNSCLC-like LCNEC could be found, underscoring the importance of histopathological confirmation. 

AFGELEIDE BEELDVORMINGS BIOMARKERS

In Hoofdstuk 2 hebben we een systematische literatuuronderzoek uitgevoerd naar de relatie tussen radiomics en tumorbiologie. Op twee onderzoeken na $(n=39)$ lieten alle onderzoeken zien dat radiomische kenmerken afgeleid van echografie, $C T$, PET en/of MR significant geassocieerd zijn met een of meer specifieke biologische tumorsubstraten.

In Hoofdstuk 3 hebben we verschillende potentieel interessante kunstmatige intelligentie-tools voor de klinische praktijk besproken, zoals automatische segementatie in de context van volumetrische behandelingsresponsevaluatie (volumetrische RECIST).

\section{DEEL II - PARADIGMAVERSCHUIVING NAAR HET GEBRUIK VAN BIOMARKERS VAN BEELDVORMING EN GENEXPRESSIE VOOR DE DIAGNOSE EN BEHANDELING VAN TUMORHYPOXIE}

In Hoofdstuk 4 hebben we een literatuuronderzoek gedaan naar kenmerken van hypoxie-PET-tracers en in het bijzonder de tracer [18F]-HX4 welke verschillende voordelen en beperkingen aantoonde in vergelijking met de andere PET-tracers.

In Hoofdstuk 5/6 werd een long, hoofd hals en agnostische radiomics 'signature' op CT en FDG-PET getraind voor het classificeren van tumoren in hypoxische/niet-hypoxische groepen op basis van verschillende hypoxische fractiedrempels.

Een agnostisch CT-model om de hypoxiestatus te classificeren (HF-grenswaarde 20\%) bereikte AUC's van respectievelijk $0,79 \pm 0,16,0,76 \pm 0,18$ en $0,72 \pm 0,14$ in drie externe validatiedatasets door 5 van $\mathrm{CT}$ afgeleide radiomische kenmerken te combineren. Een agnostisch FDG-PET-model bereikte een AUC van $0,74 \pm 0,23$ in externe validatie door 10 beeldkenmerken te combineren (HF-grenswaarde $20 \%$ ).

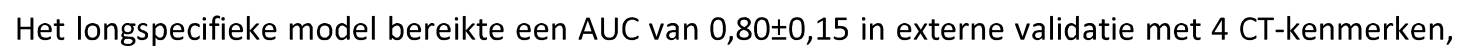
terwijl het $\mathrm{H} \& \mathrm{~N}$-specifieke model een AUC van $0,86 \pm 0,20$ bereikte in externe validatie met 6 CTkenmerken. Verder werd een significante overlevingssplitsing gevonden tussen CT-geclassificeerde hypoxielagen en 117 significante maar lage hypoxierespons gen-CT beeldvormingsbiomarkers associaties gevonden.

In Hoofdstuk 7 hebben we in twee Nederlandse trials laten zien dat in lijn met eerdere studies met [18F]-FMISO en [18F]-FAZA hypoxie PET-tracers de PET-tracer [18F]-HX4 in hoofd hals kankerpatiënten van prognostische waarde is.

In Hoofdstuk 8 hebben we vastgesteld of en in hoeverre tumormarkers die gerelateerd zijn aan hypoxie, proliferatie, DNA-schadeherstel en stamcel-heid, een prognostische waarde hebben bij HNSCC-patiënten in een gevorderd stadium wanneer ze individueel worden beoordeeld. Tumor acute en chronische hypoxie, stamcel-heid en CD8+ T-cel parameters bleken allemaal relevante en grotendeels onafhankelijke biologische factoren te zijn die samen bijdragen aan locoregionale controle.

DEEL III - PARADIGMAVERSCHUIVING NAAR BIOLOGIE-AFGELEIDE RADIOMICS BIJ DIAGNOSE EN BEHANDELING VAN LONG-, HOOFD- EN HALSKANKER

In Hoofdstuk 9 hebben we aangetoond dat we de histologieresultaten van vriescoupes mogelijk kunnen verbeteren door de toevoeging van radiomics in solitaire longnodules. Deze methode kan de chirurg helpen bij het nemen van beslissingen over het meest geschikte type operatie om een enkele nodule te verwijderen. 
In Hoofdstuk 10 hebben we ons gericht op het identificeren van peritumorale regio's op CT bij hoofdhalskankerpatiënten en deze regio's kunnen waardevolle informatie opleveren over (loco)regionale verspreiding en metastase op afstand. Uit onze analyse bleken peritumorale regio's geen voorspellende waarde te hebben voor bovengenoemde uitkomsten. Er kunnen verschillende verklaringen hiervoor zijn: 1) De onderzoekseindpunten zijn zeer complex en voorspellingsmodellen hebben moeite met het trainen van generalizeerbare modellen. 2) Er waren verschillen tussen het opleidings- en validatiecohort met betrekking tot de chemotherapie-regimes die werden gebruikt bij de behandeling van de patiënten.

In Hoofdstuk 11 hebben we een analyse uitgevoerd van CT-scans verkregen in de dagelijkse klinische praktijk van LCNEC patiënten. De radiomic-signature getraind op scans van SCLC- en NSCLC-patiënten was in staat om SCLC en NSCLC in een externe dataset te identificeren. pSCLC-achtige en pNSCLCachtige LCNEC konden echter niet worden gescheiden door dit model. De subclassificatie tussen moleculaire LCNEC-subtypen kon niet worden gemaakt op basis van beeldvormingsinterpretatie of semantische kenmerken. In deze studie konden ervaren longoncologen en thoraxradiologen redelijk onderscheid maken tussen SCLC en NSCLC-gebaseerde kenmerken die door CT-scans worden geleverd. Er kon echter geen verschil worden gevonden tussen pSCLC-achtige en pNSCLC-achtige LCNEC, wat het belang van histopathologische bevestiging onderstreept. 